\title{
СТАТИСТИКА И ДИНАМИКА ВОВЛЕЧЕНИЯ В ТЕРРОРИСТИЧЕСКУЮ ДЕЯТЕЛЬНОСТЬ
}

\section{STATISTICS AND DYNAMICS OF INVOLVEMENT IN TERRORIST ACTIVITIES}

\section{Z. Gadzhimalikova}

Summary. The article reveals the main criminological features of involvement in terrorist activities.

The purpose of the study: to conduct a comprehensive study of statistics and dynamics of involvement in terrorist activities.

Methods: analysis, synthesis, modeling, qualitative and quantitative comparison.

Results: the use of historical analysis briefly reveals the activities of terrorist organizations to involve citizens in terrorist activities. The methods and methods of involvement in terrorist activities are analyzed. The main quantitative indicators are studied. The author reveals the internal processes of involvement in terrorist activities, as well as their influence on the personality of the person involved.

Conclusions: the study confirmed that the main factor of involvement in terrorist activities is its socio-economic status.

In the system of prevention of youth involvement in terrorist activities, the Federal social youth policy of the state is essential. Social protection of young people is an important area for countering their involvement in terrorist activities. In this regard, young people should become the center of social policy of the state.

Keywords: terrorist activity, involvement in terrorist activity, determinants of involvement, methods of involvement in terrorist activity, statistical data, the enabler.

\author{
Гаджималикова Зейнаб Ханларовна \\ Адъюнкт, Краснодарский университет \\ МВД России РФ \\ zaynab-1102@yandex.ru
}

Аннотация. В статье раскрываются основные криминологические особенности вовлечения в террористическую деятельность.

Цель исследования: провести комплексное изучение статистики и динамики вовлечения в террористическую деятельность.

Методы: анализ, синтез, моделирование, качественное и количественное сравнение.

Результаты: методом применения исторического анализа кратко раскрыта деятельность террористических организаций по вовлечению граждан в террористическую деятельность. Проанализированы способы и методы вовлечения в террористическую деятельность. Исследованы основные количественные показатели. Автором раскрыты внутренние процессы вовлечения в террористическую деятельность, а также их влияние на личность вовлекаемого лица.

Выводы: Проведенное исследование подтвердило, что основным фактором вовлечения в террористическую деятельность является ее социально-экономическое положение.

В системе профилактики вовлечения молодежи в террористическую деятельность существенное значение имеет федеральная социальная молодежная политика государства. Социальная защита молодежи является важным направлением противодействия вовлечению ее в террористическую деятельность. В этой связи молодежь должна стать центром социальной политики государства.

Ключевые слова: террористическая деятельность, вовлечение в террористическую деятельность, детерминанты вовлечения, способы вовлечения террористической деятельности, статистические данные, вовлекатель.

В научной и юридической литературе террористическая деятельность рассматривается, как самостоятельное преступное явление и способы вовлечения в него не ограничены законодательством.

Мы согласны с мнением тех авторов, которые считают, что анализ социальной детерминации предполагает применение метода историзма, т.е. познания явлений в развитии его прошлого к настоящему и от него к будущему, что позволяет обоснованно не только объяснить детерминацию, но и прогнозировать ее дальнейшее развитие. 
Так, в 90-е годы прошлого столетия враждебные силы, опираясь на возможности ряда ближневосточных экстремистских религиозных структур, способствовали распространению в республиках Северного Кавказа традиционно чуждых кавказским мусульманам радикальных политизированных течений исламского фундаментализма. В результате пропагандистских усилий радикалов часть населения региона попала под влияние их идеологических установок. [3, с. 104-108]

После нескольких безуспешных попыток насильственного свержения существующей власти в 90-е годы прошлого столетия радикалы перешли к тактике использования идеологических приёмов и методов противостояния.

В качестве примера вовлечения в террористическую деятельность эмиссарами зарубежных религиозных организаций можно привести основанное лидером дагестанских ваххабитов Б.М. Кебедовым в г. Кизилюрте медресе «Хикма», которое беспрепятственно функционировало в 1991-1999 годы. В данном учебном заведении ежегодно обучалось до 700 учеников. Кебедов имел выход на ряд посольств арабских стран, откуда и получал интересующую его литературу. Многие выпускники этих учебных заведений в дальнейшем становились главными рассадниками религиозного радикализма, сепаратизма и экстремизма по всей стране.

Немалая часть экстремистов была завербована и подготовлена в зарубежных религиозных учебных заведениях. По данным спецслужб, с начала 90-х годов прошлого столетия для обучения в религиозных образовательных учреждениях за границу выехало более 2000 дагестанцев.

Исследование показывает, что наиболее активная вербовка велась именно в мечетях, где имамами были выпускники этих учебных заведений, под воздействием их экстремистских проповедей в салафитских мечетях прихожане вступали в ряды подполья, постепенно расширяя его пособническую базу.

Результаты анализа свидетельствуют о том, что наиболее одиозные члены подполья были вовлечены в террористическую деятельность также и в местах лишения свободы.

Помимо вовлечения в подполье путём идеологического воздействия, применялись и другие способы. Как отмечает А.М. Гамидов, одна из причин попадания молодёжи в сети экстремистских течений - поиск источников дохода, а также осознание невозможности утвердиться в обществе $[1$, с. 3]. И поэтому социальная база террористов расширяется за счет безработных, а также подростков из малообеспеченных семей.

Пополнение численности подполья осуществлялось, в основном, из жителей Северокавказского федерального округа. Вместе с тем, в состав группировок вовлекались также и выходцы из других регионов России. Установлено участие в террористических ячейках республики жителей Ставропольского края, Республики Башкортостан, Республики Татарстан, Астраханской и Ростовской областей. Активная вербовочная работа в настоящее время ведется в северных регионах России: Ханты-Мансийском и Ямало-Ненецком автономных округах, Тюменской области и т.д.

Так, в результате контртеррористической операции, проведённой подразделениями Национального антитеррористического комитета (НАК) 21 апреля 2018 г. в г. Дербенте и одноимённом районе, убиты 11 боевиков. По данным НАК они были членами одной из международных террористических организаций, имели связь с группой террористов, задержанных в конце 2017 года в г. Санкт-Петербурге, готовили масштабные террористические акты в городах республики в предстоящие майские праздники. Один из террористов был опознан как житель г. Нефтеюганска Александр Свистак.

Начиная с 2013 года, в результате принятых на государственном уровне мер и активности правоохранительных и силовых структур удалось добиться коренного перелома ситуации в стране, который выразился в устойчивой тенденции к спаду террористической активности, снижении числа территориальных ячеек и их участников.

Этому способствовали также и сами террористические структуры. Надеясь на налаживание каналов получения вооружения и финансовых ресурсов от запрещённой В РФ международной террористической организации (МТО) «Исламское государство» (ИГ), с 2014 года большинство лидеров подполья республики демонстрировали безусловную поддержку его линии, временно отказались от наращивания активности в республике и сосредоточили основные усилия на пополнении рядов МТО. Кроме того, целью такой поддержки явилась подготовка боевиков в условиях масштабных боевых действий на территории Ирака и Сирии, и последующего формирования из них боевого ядра подполья для использования в дальнейшем на территории страны. [5]

По данным МВД по РД, в 2015-2016 гг. были ликвидированы лидеры МТО «Имарат Кавказ» А. Кебеков и М. Сулейманов и «Амир Вилайята Дагестан» К. Саидов, уничтожены лидеры подполья, присягнувшие ИГ, Г.А. Абдуллаев и Р.М. Асельдеров [4]. 
В настоящее время вербовщики террористических организаций целенаправленно используют среду трудовых мигрантов для радикализации не сумевших адаптироваться в России граждан ближнего зарубежья, стремятся приобщить их к, так называемым, «спящим» ячейкам, которых в дальнейшем можно мобилизовать на совершение терактов.

По имеющимся в правоохранительных органах данным, в настоящее время по официальной версии, более 1200 жителей Дагестана воюет на стороне боевиков ИГ. Среди российских регионов Дагестан считается главным поставщиком террористов.

Примером успешного воздействия через социальные сети на объект предназначения может служить вербовка, так называемого, «Кизлярского стрелка» Х. Халилова, расстрелявшего у православного храма в г. Кизляре восемь женщин, из которых пять погибло. Перед терактом он выставил в социальных сетях видеообращение, в котором читает текст присяги лидеру ИГ Абу - Бакру Аль - Багдади, поместив сзади себя на стене черный флаг ИГ.

Это можно проследить также и на примере успешного профессионала-программиста тридцатилетнего Нурмагомедова Марата Казимовича, который в 2013 бросил всё - беременную жену и близких людей, налаженный бизнес в г. Москве - и уехал в Сирию. Что его привлекло в этом «аду», на территории Сирии, контролируемой «ИГ» и/или «Джебхат ан Нусра»?! Как правило, молодые «романтики» из российских (преимущественно, северокавказских) мусульман, едущие в Сирию «на джихад», черпают информацию из русскоязычных интернет ресурсов. Известный дагестанский учёный социолог Заид Абдулагатов пишет, что основная масса террористов-«джихадистов» не знают арабского языка, элементарных азов ислама и опираются на информацию исключительно из русскоязычных сайтов. Таким образом, в настоящее время основным инструментом распространения террористической и экстремистской идеологии стали, прежде всего, социальные сети и мобильные средства информационного обмена для организации скрытых каналов связи и пропаганды преступной деятельности.

По оценкам экспертов, в настоящее время в Интернете действуют свыше 10 тысяч сайтов, пропагандирующих терроризм и экстремизм. В целях локализации их деятельности принят ряд мер по наведению порядка в российском сегменте.

Кроме того, в настоящее время главной задачей в противодействии экстремизму и терроризму органов власти всех уровней является дерадикализация членов подполья, в том числе «спящих ячеек».
Как отмечает С. Сиражудинова, процесс дерадикализации весьма сложен и требует комплексного подхода, совместной работы, продуманных программ, усилий со стороны семьи или общины, и, конечно же, желания самого человека, которого коснулась болезнь радикализма. [6, с. 4]

Так, по сведениям информационного центра МВД России, за 2012 год подобных преступлений было выявлено 622, в 2013-м - 637, в 2014-м - 661, в 2015-м 1531, в 2017-м - 1871, в 2018-м - 1679. За 2019 год было выявлено 1806 преступлений террористического характера. В общей сложности правоохранительные органы зафиксировали 2227 преступлений террористического характера за 2016 год. При сравнительном анализе этот показатель стал максимальным за последние годы и значительно превышает данные, которые получали по итогам предыдущих лет. Эти статистические данные указывают на сохранение крайней актуальности террористической угрозы в стране и необходимость применения более действенных мер для достижения существенных результатов в борьбе с терроризмом.

Тенденцию роста вовлечения несовершеннолетних в совершение преступлений террористической направленности официальная статистика показывает, начиная с 2003 г. (Федеральным законом от 24 июля 2002 г. № 103 - Ф3 в уголовный закон введена статья 205.1 (Вовлечение в совершение преступления террористического характера) [7, с. 1123]. Если в республиках Северного Кавказа в 2010 г. (2011 г.- 4; 2012 г.- 5; в 2013 г.2; в 2014 г.- 3; в 2015 г.- 4; в 2016 г.- 6; в 2017 г. - 14; в 2018 г.-16) было зарегистрировано всего 4 случая вовлечения несовершеннолетних в совершение преступлений террористической направленности, то в 2018 году совершенно 16 преступлений данной категории.

Передовые позиции среди республик Северного Кавказа занимает Республика Дагестан. По данным Информационного центра МВД России, в 2019 года зарегистрировано всего 7 фактов вовлечения несовершеннолетних в совершение преступлений террористической направленности (2011 г.— 2; 2012 г.— 2; в 2013 г.— 1; в 2014 г.1; в 2015 г.- 3; в 2016 г.- 3; в 2017 г. - 7; в 2018 г.- 9) [16].

Предупредительно-профилактическое значение имеет создание региональных целевых программ по противодействию вовлечению в совершение преступлений террористической направленности в субъектах Российской Федерации на основе изучения и прогнозирования криминологической ситуации в регионе, учета выявленных факторов, детерминирующих данное деяние. В данных программах следует конкретизировать объекты и субъекты профилактики, распределить 
ведомственные и межведомственные функции, разработать принципы их взаимодействия, предусмотреть кадровое обеспечение, профессиональную подготовку лиц, участвующих в предупреждении вовлечения несовершеннолетних в совершение преступлений террористической направленности.

В заключение следует отметить, что преступные сообщества экстремистского толка будут совершенство- вать свой потенциал вовлечения несовершеннолетних в совершение преступлений террористической направленности. Возможно, появятся новые средства систематического вовлечения молодежи, особенно несовершеннолетних в свои сети.

Только слаженная система обеспечения правильного развития и самореализации молодежи способна противостоять террористическому натиску.

\section{ЛИТЕРАТУРА}

1. Гамидов А. М. Условия, способствующие вовлечению несовершеннолетних в терроризм // Юридический вестник ДГУ.— Махачкала, 一 2017. — № 2.

2. Игнатов А.Н., Сапрунов А.Г. Уголовная ответственность за содействие террористической деятельности: совершенствование законодательной регламентации // Общество и право. - 2018. — № 2 (64). - С. 39-45.

3. Коровин Е. П. Содействие террористической деятельности и институт соучастия: вопросы соотношения // Материалы VI Международной научно-практической конференции. - 2015.- С. 104-108.

4. Криминология: учебник / под ред. Проф. Н. Ф. Кузнецовой, проф. Г. М. Миньковского. М., -2016.

5. МВД: «40 боевиков уничтожено в Дагестане» // «Московский Комсомолец» в Дагестане. 4-11 апреля. 2018. — № 15(1051).

6. Официальный сайт МВД России. Электронный ресурс мвд.рф/reports/item/7087734/

7. Сиражудинова С. Факторы радикализации // «Московский Комсомолец» в Дагестане. 8-15 ноября. 2017.

8. Уголовный кодекс Российской Федерации от 13 июня 1996 г. № 63-Ф3 // Собрание законодательства РФ. — 1996. — № 25. — Ст. 2954.

( Гаджималикова Зейнаб Ханларовна ( zaynab-1102@yandex.ru ).

Журнал «Современная наука: актуальные проблемы теории и практики»

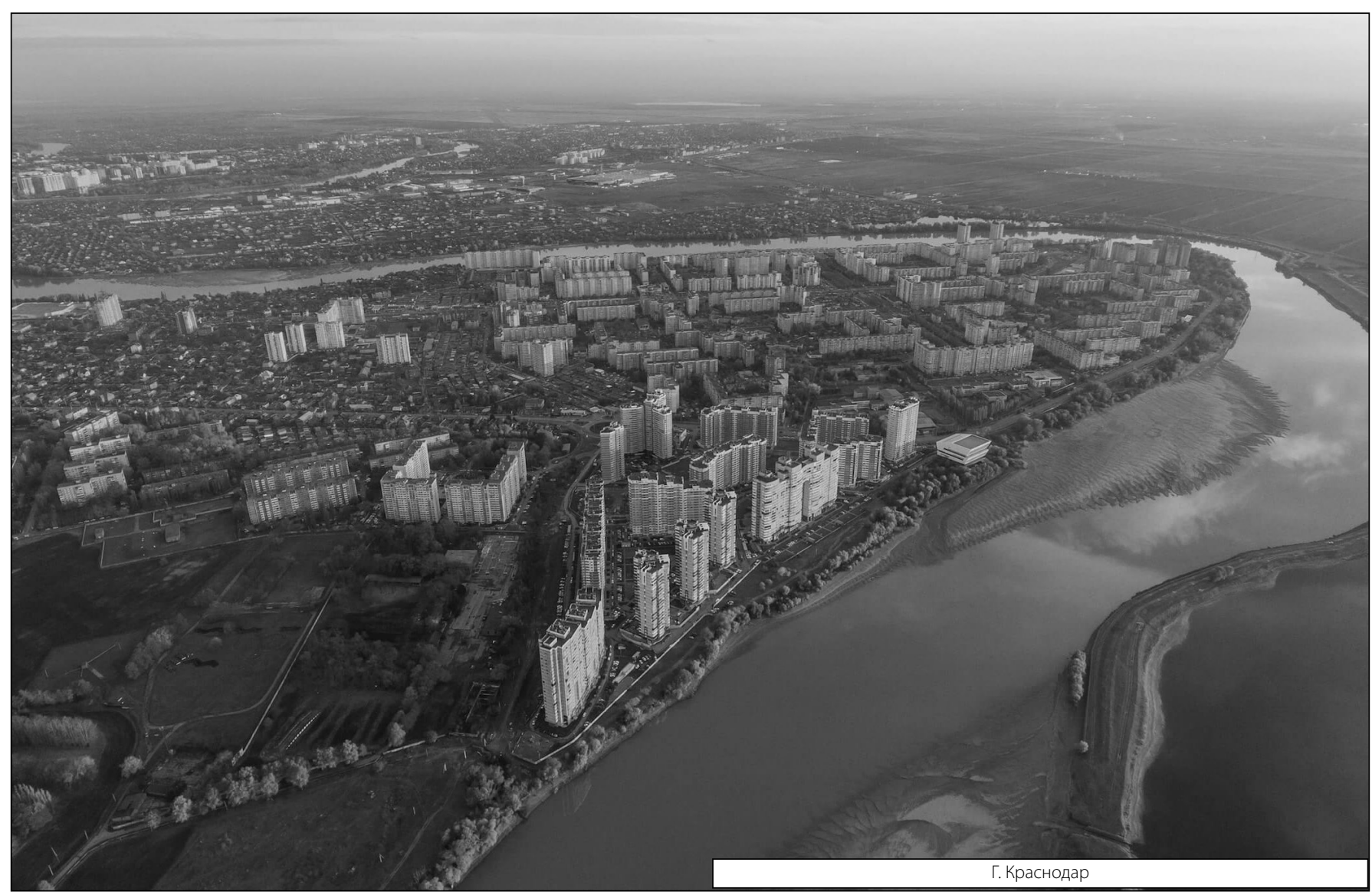

